\title{
KUALITAS PAKAN FERMENTATIF BERBAHAN KULIT UBI KAYU DENGAN INOKULAN MEP+ UNTUK KULTUR IKAN NILA GESIT (Oreochromis niloticus L.)
}

\author{
CAHIADIR ALI AKBAR, SUKANTO, Siti RUKAYAH
}

Fakultas Biologi, Universitas Jenderal Soedirman, Jalan dr. Suparno 63 Purwokerto 53122

\section{A B S T R AC T}

Feed is a major component in fish farming. However, the relatively high price of feed is very burdensome for fish farmers. Therefore a relatively low-cost solution is needed to address that problem. The use of local materials such as bran, waste mushroom, tofu, onggok starch, and skin cassava can be utilized as an alternative to reduce the needs of imported materials. However, the local materials have constraints regarding nutrition and digestibility, so an appropriate technology is required to overcome this. Improving the quality of the feed can be done by fermentation. Fermentation works by breaking macromolecules such as carbohydrates and amino acids into micromolecules, so the absorption of feed nutrients in the fish intestines become more efficient. The use of inoculants MEP+ aimed to improve the digestibility of feed, detoxification and increased the productivity of tilapia GESIT (Oreochromis niloticus). This study aimed to determine the effect of fermentation on enhancing the quality of feed nutrients made from cassava skin chips by the application of inoculant MEP+. The study was carried out experimentally using a complete randomized design. The independent variable in this study was the type of feed. Observed dependent variable was feed quality. The main parameter measured was the proximate level. Supporting parameter was the growth of tilapia GESIT. The results showed a progressive increase in the levels of nutrients of feed fermented in each treatment. The increments were recorded in treatment A from 16.15 became 21.64, in B from 13.21 became 15.46, in C from 9.66 became 11.53, and in D from 8.34 became 9.87. This result implies that the use of MEP+ fermentation inoculants could boost the nutritional content of food, with an average of the increment value of $11-15 \%$. The increment of nutrient contents in each treatment was also affected the weight gain of fish although no significant difference were observed.

KEY WORDS: Oreochromis niloticus, MEP+, fermentation, skin cassava

Corresponding Author: SITI RUKAYAH | email: rukayah.siti@ymail.com

\section{PENDAH ULUAN}

Pakan merupakan unsur terpenting dalam menunjang kehidupan dan pertumbuhan ikan. Ketersediaan pakan dalam jumlah yang cukup, tepat waktu, dan mempunyai nutrisi yang baik merupakan faktor yang sangat penting dalam kegiatan budidaya ikan. Pakan ikan menurut SNI (Standar Nasional Indonesia) tahun 1996 adalah campuran berbagai bahan pakan, hasil formulasi yang dapat meningkatkan kelulusan hidup (survival) dan pertumbuhan terhadap ikan yang dibudidayakan dan tidak mengandung cemaran yang dapat menimbulkan gangguan kesehatan terhadap ikan.

Penggunaan tepung ikan yang masih dominan dalam pembuatan pakan menyebabkan beberapa kendala, yakni karena harga dari tepung ikan yang cukup tinggi. Hal tersebut berdampak pada harga pakan yang menjadi mahal, sehingga memberatkan bagi para petani ikan. Tangko, dkk (2007) menyatakan bahwa pakan merupakan komponen biaya produksi paling tinggi yaitu $60-70 \%$. Sehingga perlu adanya pakan alternatif yang harganya murah namun berkualitas.

Bahan baku lokal seperti ampas tahu, dedak, limbah jamur dan limbah kulit ubi kayu merupakan limbah industri yang dapat dimanfaatkan sebagai bahan baku pakan. Keuntungan yang didapat dari pengunaan bahan baku lokal ini adalah harganya yang lebih murah, mudah didapat. Pemanfaatan limbah kulit ubi kayu sendiri masih rendah dan belum dapat terolah secara optimal dikarenakan kandungan serat kasarnya cukup tinggi, kandungan nutrisi yang rendah dan mengandung sianida yang bersifat toksik jika konsumsi berlebihan.

Untuk mengatasi rendahnya nilai nutrisi dari kulit ubi kayu, maka diperlukan teknologi yang dapat meningkatkan kualitas dari limbah tersebut yaitu dengan proses fermentasi. Fermentasi didefinisikan sebgai proses pemecahan karbohidrat dan asam amino secara anaerobik. Supriati (2003) mengemukakan bahwa dengan fermentasi oleh aspergilus niger, protein onggok dapat ditingkatkan dari 2,2\% menjadi 25,6\%. Proses fermentasi mampu merombak protein nabati yang sulit dicerna agar lebih mudah dicerna seperti, selulosa, hemiselulosa, dan polimer-polimernya menjadi gula sederhana atau turunanya (Santoso, 1989). Fermentasi pada suatu bahan dapat meningkatkan kandungan protein, perbaikan kecernaan serta terbentuknya berbagai asam amino, enzim dan vitamin (Muljohardjo, 1988).

Probiotik didefinisikan sebagai suplementasi sel mikroba utuh (tidak harus hidup) atau komponen sel mikroba pada pakan atau lingkungan hidupnya yang menguntungkan inangnya (Fuller, 1987 dalam Irianto, 2003; Gram et al., 1999 dalam Irianto, 2003). Selanjutnya dikatakan didalam bidang akuakultur penggunaan probiotik bertujuan untuk menjaga keseimbangan mikroba dan penggendalian patogen dalam saluran pencernaan, serta perairan melalui proses biodegradasi.

Wahyudi (2008) menambahkan bahwa penambahan probiotik $\mathrm{MEP}^{+}$pada pakan mampu menekan patogenitas Aeromonas hydropylla dan berpengaruh pada kelulusan hidup ikan nila GIFT. 
Thye (2005) menyatakan probiotik selain menguntungkan inang yang dipelihara juga mampu mengurangi senyawa toksik dalam perairan seperti $\mathrm{NH}_{3}, \mathrm{NO}_{2}$, dan $\mathrm{NO}$ serta menekan populasi alga biru (blue-green algae). Dilaporkan juga bahwa mikroflora yang seimbang di jalur digesti sama artinya dengan membangun pertahanan mikroba yang merupakan proteksi mukosa dalam menghambat penyebab bakteri patogen usus (Holl, 2008; Castillo, 2008).

Salah satu produk probiotik adalah $\mathrm{MEP}^{+}$yang merupakan produk probiotik hasil pengembangan laboratorium Mikrobiologi Fakultas Biologi Universitas Jenderal Soedirman. $\mathrm{MEP}^{+}$merupakan probiotik yang didalamnya mengandung bakteribakteri isolat indegenous Gram positif non patogen yang bersifat amilolitik+, selulolitik+, proteolitik+, dan lipolitik, serta menghasilkan vitamin B12, C, dan K yang mampu bekerja untuk meningkatkan pertumbuhan ternak dan menghambat serangan penyakit (Sukanto dan Sutardi, 2009).

Penelitian ini menggunakan jenis dari ikan nila yakni, ikan nila GESIT (Genetically Supermale Indonesian Tilapia) yang merupakan hasil pengembangan dari Balai Pengkajian dan Penerapan Teknologi (BPPT) bekerja sama dengan Fakultas Ilmu Kelautan dan Perikanan Instut Pertanian Bogor serta Balai Besar Pengembangan Budidaya Air Tawar (BBPBAT). (Kementrian Kelautan dan Perikanan RI, 2010). Keunggulan dari ikan nila GESIT ini yakni pertumbuhan yang lebih cepat dibanding nila lokal, toleran terhadap lingkungan yang kurang baik, mempunyai respon yang luas terhadap pakan, serta menghasilkan keturunan jantan mencapai 98\% (Yuniarti dkk, 2007).

Hal tersebut dapat memberikan gambaran tentang pemanfaatan pakan fermentatif berbahan kulit ubi kayu yang diintroduksi $\mathrm{MEP}^{+}$untuk kultur ikan nila GESIT mengingat ikan jenis ini merupakan varietas unggul. Penelitian bertujuan untuk mengetahui: pengaruh fermentasi terhadap peningkatan kualitas nutrisi pakan berbahan kulit ubi kayu dan perlakuan yang memberikan produktivitas ikan nila GESIT terbaik.

Hasil penelitian diharapkan dapat memberikan informasi ilmiah tentang cara pemanfaatan dari limbah kulit ubi kayu yang difermentasi munggunakan inokulan $\mathrm{MEP}^{+}$untuk meningkatkan pertumbuhan ikan nila GESIT. Nuraini, (2008) mengemukakan bahwa penggunaan kulit ubi kayu fermentasi sampai $20 \%$ dalam ransum dapat meningkatkan nafsu makan ayam. Hal ini disebabkan bahan hasil fermentasi memiliki aroma dan rasa yang lebih baik dari bahan asalnya karena makanan hasil fermentasi mempunyai nilai organoleptik yang tinggi dan nilai nutrisi bahan tersebut lebih meningkat dari bahan asalnya. Nilai kandungan nutrisi hasil fermentasi kulit ubi kayu yang telah dilakukan Nuraini (2007) menggunakan Penicillium sp. terjadi peningkatan nilai gizi yaitu kadar protein kasar dari $8,11 \%$ menjadi $15,52 \%$. Pada saat protein meningkat, serat kasar mengalami penurunan dari 19,66\% menjadi $14,71 \%$, dan kadar HCN juga mengalami penurunan dari 228,4 ppm menjadi 37 ppm. Sedangkan dalam penelitian ini, tingkatan pakan hasil fermentasi kulit ubi kayu yang digunakan adalah 0\%, $25 \%, 50 \%$ dan $75 \%$.

Hipotesis yang dapat diajukan adalah: 1) fermentasi berefek meningkatkan kualitas nutrisi dan laju pertumbuhan ikan nila GESIT, 2) perlakuan yang memberikan produktivitas ikan terbaik adalah pakan fermentasi kulit ubi kayu dengan prosentase 25\%.

\section{METODE}

Alat yang digunakan dalam penelitian ini adalah kolam bak fiber yang berukuran $80 \times 50 \times 80 \mathrm{~cm}$, seser, ayakan, pengaduk, tampah plastik, ember, timbangan, milimeter blok, kamera digital, blender, gunting, terpal, alat pencetak pellet, plastik, papan penjemur pelet, kertas label, gelas ukur, kompor gas, aerator, selang, dan panci kukus.

Bahan yang digunakan dalam penelitian adalah ikan nila GESIT (Oreochromis niloticus) dengan bobot $\pm 29,5 \mathrm{~g}$ panjang $\pm 12,5 \mathrm{~cm}$, probiotik $\mathrm{MEP}^{+}$cair, $\mathrm{MEP}^{+}$tepung, vitamin ikan, onggok, limbah buidaya jamur, tepung ikan, tepung kanji, pakan fermentasi (bahan baku: dedak, ampas tahu, tepung kulit ubi kayu, dan $\mathrm{MEP}^{+}$), akuades, Kalium Permanganat $\left(\mathrm{KMnO}_{4}\right)$ 0,5\%, dan CMC (carboksil metil cellulosa)

Penelitian dilakukan di Stasiun Percobaan Fakultas Biologi Universitas Jenderal Soedirman untuk pembuatan pellet dan pemeliharaan ikan, sedangkan untuk analisa sampel dikerjakan di Laboratorium Ilmu Nutrisi dan Pakan Ternak Fakultas Peternakan UNSOED. Waktu pelaksanaan penelitian dilaksanakan selama 6 bulan, mulai bulan Agustus 2011-Januari 2012.

Metode penelitian yang digunakan adalah metodde eksperimental dengan Rancangan Dasar Acak Lengkap (RAL). Perlakuan yang dicobakan adalah dengan presentase pemberian tepung kulit ubi kayu 0\%, 25\%, 50\%, 75\%. Masing-masing perlakuan diulang sebanyak 4 kali, sehingga didapat 16 unit percobaan. Perlakukan yang dilakukan adalah sebagai berikut:

$\mathrm{A}=$ Pakan fermentasi dengan kulit ubi kayu sebanyak $0 \%$ $\mathrm{B}=$ Pakan fermentasi dengan kulit ubi kayu sebanyak $25 \%$ $\mathrm{C}=$ Pakan fermentasi dengan kulit ubi kayu sebanyak 50\% $\mathrm{D}=$ Pakan fermentasi dengan kulit ubi kayu sebanyak 75\%

Variabel bebas penelitian adalah jenis pakan. Variabel tergantung penelitian adalah kualitas pakan. Parameter utama yaitu kadar proksimat. Parameter pendukung adalah pertumbuhan ikan nila GESIT, kandungan fisika-kimia perairan.

Bak fiber sebanyak 16 unit dibersihkan dengan Kalium Permanganat $\left(\mathrm{KMnO}_{4}\right)$ 0,5\% didiamkan selama 24 jam, selanjutnya dibilas dengan air bersih. Akuarium dilengkapi dengan aerator, kemudian diisi dengan air sebanyak 24 liter dan diberi $\mathrm{MEP}^{+}$sebanyak $24 \mathrm{cc}$. Air yang digunakan adalah air sumur yang telah di aerasi selama $2 \times 24$ jam sebelum digunakan. Kemudian pada bak fiber diberi naungan dengan tanaman apu-apu sebanyak $25 \%$ dari luas permukaan bak fiber.

Ampas tahu, onggok, limbah jamur, dedak, dan tepung kulit ubi kayu ddicampurkan hingga merata an tambahkan air secukupnya sampai adonan memadat. Selanjutnya adoanan dikukus selama 15 menit. Kemudian ditiriskan, ditambah MEP tepung sebanyak 7,5 $\mathrm{gr} / \mathrm{kg}$ selanjutnya diinkubasi selama 4 hari. 
Tahapan pembuatan pelet yakni tepung ikan, pakan yang telah difermentasi, aci, air, dan vitamin ikan aquamin dicampur dan diaduk hingga rata. Kemudian adonan dicetak menggunakan alat pencetak pellet. Setelah dicetak, dilakukan penjemuran hingga pellet kering kemudian disemprot dengan $\mathrm{MEP}^{+}$yang telah dilarutkan dalam air dengan volume $1 \mathrm{cc.l}^{-1}$ sampai rata dan diberi CMC.

Ikan nila GESIT yang digunakan dalam penelitian ditebar sebanyak sepuluh ekor ke dalam masing-masing bak yang berjumlah enam belas unit secara merata. Sebelum dilakukan pengujian ikan terlebih dahulu diaklimatisasi selama satu minggu untuk menyesuaikan diri terhadap temperatur lingkungan dan pakan tambahan. Selama aklimatisasi ikan diberi pakan komersial (kadar protein \pm $24 \%$ ) berbentuk pelet sebanyak 3\% dari biomassa total ikan diberikan dua kali sehari pada pagi hari (07.00-08.00 WIB) dan sore hari (17.00-18.00 WIB) Sehingga setiap pemberian pakan diberikan sebanyak 1,5\% dari biomassa ikan.

Pakan diberikan dua kali sehari pada pagi (07.00-08.00 WIB) dan sore hari (17.00-18.00 WIB), dengan jumlah pakan yang diberikan masing-masing 1,5\% dari biomassa ikan pakan yang diberikan sesuai dengan perlakuan masingmasing. Sehingga total pemberian pakan setiap harinya adalah 3\% dari biomassa ikan. Ikan diambil keseluruhan dari masing-masing bak, kemudian ditimbang untuk mengukur bobot ikan. Pengukuran dilakukan setiap dua minggu sekali.

Pakan hasil fermentasi dianalisis proksimat untuk mengetahui nilai nutrisi. Sebagai data pendukung pertambahan bobot ikan nila GESIT juga dianalisis dengan one way analisis of variance (ANOVA) pada tingkat kepercayaan 95\% dan 99\%. Apabila terdapat perbedaan yang signifikan maka akan dilanjutkan dengan uji Beda Nyata Terkecil (BNT), untuk mengetahui pengaruh pemberian pakan fermentatif yang optimal. Data penunjang berupa kualitas air dianalisis secara deskriptif.

\section{HASIL DAN PEMBAHASAN}

Hasil penelitian mengenai kualitas pakan fermentatif berbahan kulit ubi kayu yang berbeda dengan inokulan $\mathrm{MEP}^{+}$untuk kultur ikan nila GESIT diperoleh kandungan proksimat pakan sebelum dan sesudah fermentasi ( Tabel 1). Terjadinya peningkatan kadar air pada pakan hasil fermentasi. Menurut Steinkrauss, 1995 air merupakan salah satu produk hasil fermentasi, hal ini dikarenakan selama fermentasi terjadi proses metabolisme yakni pemecahan karbohidrat oleh mikroba. Peningkatan kadar abu disebabkan oleh vitamin yang terbentuk oleh bakteri selama proses fermentasi khususnya vitamin B12.
Diamana vitamin B12 juga mengandung unsur $\mathrm{N}$ dan Cobalt (Co). Lidiasari (2006) melaporkan bahwa produk hasil fermentasi pada umumnya memiliki kadar abu yang lebih besar. Peningkatan kadar protein pada pakan hasil fermentasi dikarenakan agen pemfermentasi dapat beradaptasi dengan baik pada substrat, sehingga meningkatkan massa mikroba. Dimana mikroba tersebut merupakan protein sel tunggal yang mengandung protein cukup besar. Indrawan (2005) menyatakan, mikroba merupakan protein sel tunggal yang secara tidak langsung mampu menigkatkan kandungan protein.

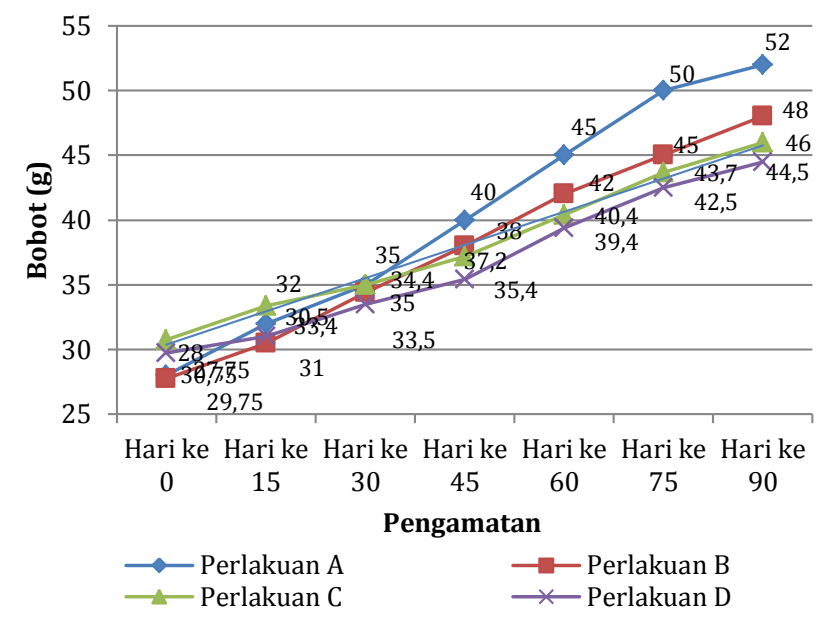

Gambar 1. Grafik pertambahan bobot ikan nila GESIT

Penurunan kadar lemak disebabkan aktivitas enzim lipase dan amilase yang bekerja dalam memecah lemak dan amilum, sehingga kandungan lemak kasar selama fermentasi mengalami penurunan. Sedangkan penurunan kadar serat kasar disebabkan karena adanya pemecahan hemiselulosa, yang disebabkan oleh bakteri selulolitik dari probiotik untuk sintesis sel. Oladunmoye (2006) menyatakan bahwa penurunan kadar serat kasar disebabakan oleh kemampuan mikroba fermentasi untuk menghidrolisis dan memmetabolisasi serat kasar sebagai komponen karbohidrat untuk mengsintesis biomassa sel. Secara berurutan nilai pertambahan bobot rata-rata akhir ikan nila GEIST terbaik adalah perlakuan A 52 gram, perlakuan B 48 gram, perlakuan C 46 gram, dan perlakuan D 44,5 gram (Gambar 1).

Tabel 1. Hasil analisis proksimat pakan fermentarif berbahan kulit ubi kayu dengan inokulan MEP+ sebelum dan sesudah fermentasi.

\begin{tabular}{lrrrrrrrr}
\hline \multirow{2}{*}{ Spesifikasi } & \multicolumn{2}{c}{ A } & \multicolumn{2}{c}{ B } & \multicolumn{2}{c}{ C } & \multicolumn{1}{c}{ D } \\
\cline { 2 - 9 } & \% Awal & \% Akhir & \% Awal & \% Akhir & \% Awal & \% Akhir & \% Awal & \% Akhir \\
\hline Kadar Air & 26,89 & 34,25 & 21,72 & 25,59 & 21,59 & 23,11 & 16,56 & 34,14 \\
Kadar Abu & 12,72 & 14,64 & 9,91 & 1264 & 11,13 & 16,29 & 6,52 & 19,10 \\
Protein Kasar & 16,15 & 21,64 & 13,21 & 15,46 & 9,66 & 11,53 & 8,34 & 9,87 \\
Lemak Kasar & 700 & 3,33 & 4,96 & 1,92 & 4,93 & 1,62 & 2,38 & 1,01 \\
Serat Kasar & 37,63 & 29,61 & 32,10 & 25,25 & 24,23 & 19,38 & 18,37 & 15,79 \\
BETN & 26,50 & 30,78 & 39,82 & 44,75 & 50,05 & 51,18 & 6438 & 54,23 \\
\hline
\end{tabular}

Keterangan:

$\mathrm{A}=$ Pakan fermentatif dengan kandungan kulit ubi kayu $0 \%$,

$\mathrm{B}=$ Pakan fermentatif dengan kandungan kulit ubi kayu $25 \%$,

$\mathrm{C}=$ Pakan fermentatif dengan kandungan kulit ubi kayu 50\%,

$\mathrm{D}=$ Pakan fermentatif dengan kandungan kulit ubi kayu $75 \%$ 
Tabel 2. Hasil Pengukuran Fisika-Kimia Medium Budidaya Ikan Nila GESIT (Oreochromis niloticus L.)

\begin{tabular}{llrl}
\hline No. & Parameter & Nilai & Metode \\
\hline 1 & Suhu Air (T) & $24-25 \mathrm{C}$ & SNI 2005:06-6989.23 \\
2 & Derajat Keasaman (pH) & $6-7$ & APHA 1992:450 0- $\mathrm{H}^{+} .4-65$ \\
3 & Dissolved Oxygen (DO) & $4,56 \mathrm{mg} / \mathrm{l}$ & SNI 2004:06-6989.31-4004 \\
4 & Nitrit $\left(\mathrm{NO}_{2}\right.$ ) & $0,0164 \mathrm{mg} / \mathrm{l}$ & SNI 1991:06-2484-1991 \\
5 & Biochemical Oxygen Demand (BOD) & $3,80 \mathrm{mg} / \mathrm{l}$ & SNI 2004:06-6989.15-2004 \\
6 & Chemical Oxygen Demand (COD) & $24 \mathrm{mg} / \mathrm{l}$ & SNI 2004:06-6989.15-2004 \\
\hline
\end{tabular}

Berdasarkan analisis proksimat pakan fermentatif sebelum dan setelah fermentasi, semakin sedikit kadar kulit ubi kayu yang terkandung dalam pakan fermentatif maka kandungan nutrisi dalam pakan tersebut tinggi, begitu pula sebaliknya. Rendahnya pertumbuhan karena pada kulit ubi kayu mengandung asam sianida ( $\mathrm{HCN})$. Karena $\mathrm{HCN}$ diketahui dapat menghambat aktivitas sistem enzim yang berperan dalam rantai respirasi sel sehingga menyebabkan aktivitas metabolismenya terhambat. Berdasarkan hasil ananlisis variansi (ANOVA) menunjukkan bahwa perlakuan pakan fermentatif berbahan kulit ubi kayu terhadap pertambahan bobot ikan nila GESIT antar perlakuan tidak berbeda nyata dengan nila $\mathrm{F}$ hitung (0.6087) < F tabel 0,05 (3.49).

Kisaran suhu air pada bak kolam sebesar $25-26^{\circ} \mathrm{C}$. Suhu tersebut dapat dikatakan menudukung pertumbuhan ikan nila. Arie (2000) menyatakan ikan nila mampu mentolerir suhu $14-38^{\circ} \mathrm{C}$, namun suhu air yang optimum bagi pertumbuhan ikan nila berkisar antara $25-38^{\circ} \mathrm{C}$. Kisaran $\mathrm{pH}$ pada bak kolam 6-7 cukup layak untuk pertumbuhan ikan nila. Setiap organisme memiliki batasan-batasan toleransi tertentu terhadap pH perairan (Alaerts dan Santika, 1987). Arie (2000) menyatakan ika nila tumbuh ideal pada kisaran pH 7-8.Kandungan oksigen terlarut 4,56 mg/l memenuhi syarat untuk mendukung kehidupan organisme. Kadar oksigen terlarut sebanyak 5-6 ppm dianggap paling ideal untuk pertumbuhan dan perkembangan ikan (Chapman,2002). Ikan nila dapat mentolerir kandungan oksigen sebesar $2 \mathrm{mg} / \mathrm{l}$. namun untuk tumbuh optimum ikan nila membutuhkan lebih dari $3 \mathrm{mg} / \mathrm{l}$ (Wardoyo, 1981). Pengukuran nitrit $\left(\mathrm{NO}_{2}\right)$ pada perairan didapatkan nilai 0,0164 mg/l. Menurut Zonneveld et al. (1991) kadar nitrit yang masih dapat ditolerir ikan nila mencapai $\leq 0,5 \mathrm{mg} / \mathrm{l}$. Nitrit beracun terhadap ikan karena dapat mengoksidasi $\mathrm{Fe}^{2+} \mathrm{di}$ dalam hemoglobin, sehingga kemampunan darah untuk mengikat oksigen sangat merosot (Ghufran et al., 2005).

Berdasarkan hasil pengukuran fisika-kimia perairan kolam budidaya dapat dikatan sebagai kualitas yang masih memenuhi syarat untuk budidaya ikan nila GESIT. Kualitas air yang baik mendorong kesehatan ikan dalam budidaya, ikan yang sehat akan memiliki sistem kekebalan tubuh yang baik sehingga dapat mencegah serangan penyakit.

\section{KESIMPULAN DAN SARAN}

Fermentasi dengan inokulan probiotik $\mathrm{MEP}^{+}$dapat meningkatkan kualitas pakan berbahan kulit ubi kayu. Perlakuan pakan fermentasi dengan kandungan kulit ubi kayu sebanyak 25\% bukan merupakan perlakuan pakan terbaik. Perlu penelitian lebih lanjut mengenai pemanfaatan kulit ubi kayu dengan dosis dibawah 25\%. Agar kualitas pakan lebih baik digunakan inokulan probiotik $\mathrm{MEP}^{+}$dalam fermentasi.

\section{DAFTAR REFERENSI}

Adrianto TT. 2005. Pedoman praktis budidaya ikan nila. Jakarta: Absolut.

Anonim. 2003. Produksi tanaman padi dan palawija di Indonesia. Jakarta: Biro Pusat Statistik.

Amri K, Khairuman. 2003. budidaya ikan Nila secara intensif. Jakarta: Agromedia Pustaka.

Arie U. 2000. Pembenihan dan pembesaran Nila GIFT. Bogor: Penebar Swadaya.

Balitnak. 1994. Pemanfaatan limbah pertanian dan limbah pengolahan tapioka/sagu sebagai pakan ternak. Warta Penelitian dan Pengembangan Pertanian. 4:7.Bautista, M. 1981. Food formulating and feeding. training and extension aquaculture departement. Southern Asia fisheries Development Center-Tigbauan Ho.

Beal JD, Niven SJ, Brooks PH, Gill BP. 2005. Variation in short chain fatty acid and ethanol concentration resulting from the natural fermentation of wheat and barley for inclusion in liquid diets for pigs. Journal of the Science of Food and Agriculture. 85(3): 433-40

Budiasih T. 2006. Tinjauan histologis intestinum tenue ayam broiler akibat pemberian probiotik MEP+ dengan Lama waktu berbeda. Fakultas Biologi Universitas Jenderal Soedirman-Purwokerto.

Djajasewaka H. 1999. Pakan ikan. Jakarta: CV. Yasaguna

Darmawan. 2006. Pengaruh kulit umbi ketela pohon fermentasi terhadap tampilan kambing kacang jantan. Jurnal Ilmiah IlmuIlmu Peternakan. 9(2):115-122.

Enie AB. 1989. Teknologi pengolahan singkong [Pros. Seminar Nasional Penigkatan Nilai Tambah Singkong] Fakultas Pertanian Universitas Padjajaran-Bandung.

Feliatra, Effendi I, Suryadi E. 2004. Isolasi dan identifikasi bakteri probiotik dari ikan kerapu macan (Ephinepelus fuscogatus) dalam upaya efisiensi pakan ikan. Jurnal Nature Indonesia. 6 (2):75-80.

Foo HL, Loh TC, Lim YS, Shukriyah MH, Khufli CN, Law FL. 2003. Effects of fermented fruits on growth performance, shedding of Enterobacteriaceae and lactic acid Bacteria and plasma cholesterol in rats. Pakistan Journal of Nutrition. 2(4):228-233.

Fuller R. 1992. History and development of probiotik. In: Fuller R, editor. Probiotic: The Scientific Basis. London: Chapman dan Hall. pp. 1-8.

Handayani AD. 2000. Efisiensi pakan dan pertumbuhan ikan Nila Gift (Oreochromis sp) yang diberi pakan buatan dengan proporsi berbeda bahan nabati dan hewani [skripsi]. Fakultas Biologi Universitas Jenderal Soedirman-Purwokerto.

Handayani DI. 2009. Uji petik performa induk GESIT pada dua Kabupaten di Jawa Barat dan Jawa Tengah.

Hardiantho D, Prayoga T, Kusuma A. 2008. Produksi calon induk Nila gesit dan Nila unggul. [diunduh 27 Januari 2012]. Tersedia pada: http:// www.bbpbat.net.

Hidayat N. 2010. Efektifitas pemanfaatan pakan dengan probiotik MEP+ pada Ikan Nila Gift dalam sistem KJA Waduk Wadaslintang. Fakultas Biologi Universitas Jenderal SoedirmanPurwokerto.

Pradiva MI. 2011. Pengaruh penambahan MEP+ pada pakan terhadap kepadatan Enterobacteriaceae dalam usus Ikan Nila 
Gift (Oreochromis niloticus L.). Fakultas Biologi Univesitas Jenderal Soedirman-Purwokerto.

Irianto A. 2003. Probiotik akuakultur. Yogyakarta: Gajah Mada University Press..

Jalaludin S, Yin OS. 1972. Hydrocyanic acid (HCN) tolerance of the hen. Malaysian Agricultural Research 1:77-79.

Klahan R, Areechon N, Yoonpundh R, Engkagul A. 2009. Characterization and activity of digestive enzymes in different sizes of Nile tilapia (Oreochromis niloticus L.). Kasetsart Journal (Natural Science). 43(1):143-53.

Laining A, Rachmansyah. 2002. Komposisi nutrisi beberapa bahan baku lokal dan Nila kecernaan proteinya pada Ikan Kerapu Bebek, Cromileptis altivelis. J. Pen. Per. Indonesia, Edisi Akuakultur. 8(2):45-51.

Mudjiman A. 2002. Makanan ikan. Jakarta: Penebar Swadaya. Hal. 100-151.

Muhidin. 2001. Peningkatan kandungan protein kulit umbi ubi kayu melalui proses fermentasi. Jurnal Matematika dan Sains. 6(1): $1-12$.

Muljohardjo M. 1988. Teknologi pengawetan pangan. Edisi ketiga. Terjemahan. Jakarta: UI Press.

Nuraini. 2008. Penggunaan ransum yang mengandung produk kulit umbi ubi kayu fermentasi dengan Penicillium sp dan pengaruhnya terhadap pertumbuhan broiler. Jurnal Agribisnis Peternakan. 4 (2):42-50.

Purnami MI. 2005. Deteksi dan identifikasi mikroba amilolitik, selulolitik, limpolitik, dan proteolitik pada mikroba MEPP (Mikroba Efektif Peningkatan Produksi)[Skripsi]. Purwokerto: Fakultas Biologi, Universitas Jenderal Soedirman.

Purnomohadi M. 2006. peranan bakteri selulolitik cairan rumen pada fermentasi jerami padi terhadap mutu pakan. Malang: Jurnal Protein. 13(2).

Rahayu SP. 2000. Pemanfaatan hasil fermentasi limbah industri sebagai campuran pakan ikan gurami (Osphronemus gouramy). Purwokerto: Fakultas Biologi, Universitas Jenderal Soedirman.

Russell PJ, Geary TM, Brook PH, Campbell A. 1996. Performance, Water use and effluent output of weaner pigs fed ad libitum with either dry pellets or liquid feed and the role of microbial activity in the liquid feed. Journal of the Science of Food and Agriculture. 72:8-16.

Sasongko P. 2009. Detoksifikasi umbi gadung (Dioscorea hispida Dennst.) melalui proses fermentasi menggunakan kapang Mucor sp. Jurnal Teknologi Pertanian. 10(3): 205-214.
Sujono. 2001. Tampilan produksi semen ayam Arab yang diberi pakan mengandung berbagai aras bekatul terfermentasi dengan Rhizopus oligoporus [diesrtasi]. Surabaya: Program Pasca Sarjana, Universitas Airlangga.

Sukanto. 2008. Instalasi produk $\mathrm{MEP}^{+}$(Mikroba Efektif Produktif) Purwokerto: Unit Uji Fakultas Biologi, Universitas Jenderal Soedirman.

Sukanto, Sutardi TR. 2008. Pengembangan budidaya ayam broiler secara non konvesional melalui pemberian probiotik MEP+. Jurnal Pengembangan Penerapan Teknologi. 6(1):397-409.

Sukanto, Sutardi TR. 2009. Teknologi pembuatan pakan produk fermentasi (silase) untuk ternak ruminan. Seminar Pengawasan Mutu Pakan dalam Rangka Peningkatan Ketahanan Pangan. Soropadan: Ditjen Peternakan dan Dinas Pertanian Propinsi Jawa Tengah.

Susilo U, Hariyadi B. 1996. Studi efisiensi pakan pada ikan Gurami (Ospronemus Gourami Lac.). Untuk Evaluasi Kebiasaan Makan. Jurnal Biosfera. 9:25-30.

Tangko AM, Mansyur A, Reski. 2007. Penggunaan probiotik pada pakan pembesaran ikan Bandeng dalam keramba jaring apung di laut. Jur. Riset Akuakultur. II (1):33-40.

Widiyati A, Sunarno MTD. 2010. Dampak penggunaan pakan buatan terhadap keberlangsungan perikanan budidaya di perairan waduk (Studi Kasus Waduk Cirata). Semiloka Nutrisi dan Teknologi Pakan Ikan/Udang. Bogor: Badan Research Kelautan \& Perikanan, Ikatan Sarjana Perikanan Indonesia.

Widyastuti E. 2005. Daya dukung perairan waduk PB Soedirman kaitanya dengan budidaya ikan dalam keramba jaring apung. Prosiding Seminar Nasional dan Kongres Biologi XIII. Yogyakarta: Fakultas Biologi, Universitas Gadjah Mada.

Widyastuti E, Sukanto, Siti Rukayah. 2010. Upaya pelestarian pemanfaatan waduk Wadaslintang bagi budidaya keramba jaring apung menggunakan pakan fermentasi dengan kandungan protein terbatas. Presentasi Seminar Nasional Limnologi V-2010 di Bogor.

Widyastuti E, Sukanto, Siti Rukayah. 2010. Upaya pelestarian pemanfaatan waduk dengan budidaya keramba jaring apung mini dan pakan ramah lingkungan [Laporan Penelitian] Purwokerto: Fakultas Biologi, Universitas Jenderal Soedirman.

Yulianti P, Kadarini T, Rusmaedi, Subandiyah S. 2003. Pengaruh padat penebaran terhadap penebaran dan pertumbuhan dan sintasan dederan ikan Nila GIFT (Oreochromis niloticus) di kolam. Jurnal Ikhtiologi Indonesia. 3(2):63-66. 